\title{
Appraising Policy, legal and Institutional Frameworks used in promoting Sustainable Sanitation Management Approaches in Mavoko Municipality within Machakos County
}

\author{
Juliana Kamanthe Muia Mutua \\ Centre for Advanced Studies in Environmental Law and Policy \\ University of Nairobi \\ Nairobi, Kenya \\ Dr. Jones Agwata \\ Centre for Advanced Studies in Environmental Law and Policy \\ University of Nairobi \\ Nairobi, Kenya \\ Dr. Stephen Anyango \\ Centre for Advanced Studies in Environmental Law and Policy \\ University of Nairobi \\ Nairobi, Kenya \\ Prof. Nicholas Oguge \\ Centre for Advanced Studies in Environmental Law and Policy
}

\begin{abstract}
The objective of the study was to appraise the existing policies, legal and institutional frameworks and their influence in promoting sustainable sanitation management. The study site covered the urbanizing areas of Athi River, Katani, Kinanie, Mlolongo and Syokimau. A cross sectional study design was adopted and both quantitative and qualitative data collected to achieve the objectives of the study. 385 house hold respondents were interviewed. Simple random and purposive sampling methods were used to administer household questionnaires to standalone houses and comprehensive housing schemes. Interviews with Key Informants from the National Government, County Government of Machakos, Mavoko Water and Sewerage Company and Export Processing Zone Authority among other service providers were conducted. Quantitative data was analyzed using descriptive statistics and presented in tables, frequencies and percentages. A content analysis from qualitative data was developed to come up with thematic issues from the interviews. The study established that Residents were not aware of relevant policies on sanitation management, were not complying with the provisions of the Laws on sanitation management while the institutional frameworks were performing poorly due to institutional overlaps and differences. There are negligible budgetary provisions for the sanitation sector and these factors have hindered the desired impact to bring positive change for sanitation management approaches used in the area. Key recommendations made are to sensitize and raise Residents awareness on the policies and laws that provide for sanitation management, clarify mandates of Institutions providing services in the municipality and increase budgetary allocations to sanitation.
\end{abstract}




\section{INTRODUCTION}

Policies, legal and institutional frameworks are important in creating enabling environments to promote sanitation. World Health Organization, WHO (2018) defines policies, rules and allocation as mechanisms that provide the basis for programmes or services. They are implemented through laws, regulations, practices of service providers contained in building codes, planning regulations and contracts, economic incentives and assignment of rights and responsibilities to institutions for development and implementation of programmes

\section{Importance of sanitation Management}

Policies are considered critical for creating an enabling environment for improving access to sanitation and hygiene services. Ekane et al (2016). Apart from the risk of disease transmission being reduced at the household level and its environs, improved sanitation contributes to better environmental quality and where it is integrated with sanitation systems combined with integrated treatment promotes resource recycling through their use of water and recovery of nutrients and energy contained in waste water. Parkinson et al (2014). It enhances the attractiveness of cities for investment making them livable. It has been illustrated too by the World Health Organization, (2012) that investing in improved sanitation gives back as the economic return on every dollar is US $\$ 5.5$ benefit.

\section{Sustainable sanitation management approaches}

According to sustainable sanitation alliance SuSanA, 2008, a sustainable sanitation system is one which is economically viable, socially acceptable, and technically and institutionally appropriate, it should also protect the environment and the natural resources. When improving an existing and/or designing a new sanitation system, sustainability criteria related to the following aspects should be considered: This is corroborated by Holden (2011) who has illustrated that for sanitation to be sustainable, provision, operation and maintenance of an entire sanitation system is necessary. Therefore the need for sustainable sanitation management approaches to improve sanitation.

\section{Background to study}

Cities are where the battle for sustainable development will be won - or lost if we fail because Cities (and urban areas) are where economic, social, cultural and environmental aspects of human activity come together in a dynamic way UN Deputy Secretary-General, (2015). Sanitation is one such key environmental aspect and as Sigel et al (2012) put it a major issue related to sustainable development in many parts of the developing world. Proper management approaches are essential in the realization of protected and conserved environment for sustainable development.

Global trends in proportion of population using improved sanitation indicate that North America, Canada, Southern parts of North America, Europe and Australia have 91-100\%, Central America and Northern parts of South America are at 76-90\%, most of Euro -Russia and the Caribbean Asia,parts of Africa like Botswana and Angola with 50-75\%. India and the rest of Africa have the lowest proportion of their population using improved sanitation at less than 50 $\%$ WHO, (2013).

It is acknowledged that rapid urbanization has compounded the ability of many African governments to provide essential services like sanitation let alone the environmental degradation that has come with it. Consequently, more people now lack access to reasonable sanitation services than in 1990; the number of those without has doubled to around 175 million. In 2010 already four in ten of Africa's one billion people lived in urban areas Jones, (2011) and by 2050, eight out of ten people in the world will be living in cities. 
Majority of urban dwellers in Africa and Asia as well as for a considerable proportion in Latin America rely on onsite sanitation systems for excreta disposal Ingallinela et al (2002). These systems have emerged as a preferred model of sanitation in cities experiencing rapid urbanization due to the high cost involved in off -site sanitation which requires conventional sewerage Pujari et al (2012). Murray (2012) notes that the trouble with these onsite sanitation toilets in the developing world is not their unavailability but rather their fast filling against governments which lack money, technology and incentive to properly manage the waste.

Still in urban areas of many developing countries, the excreta disposal situation is dramatic. Thousands of tons of sludge's from on-site sanitation (OSS) installations, i.e. from unsewered ("dry") family, public toilets and from septic tanks, are disposed of untreated. They are either used in agriculture or aquaculture or discharged indiscriminately into lanes, drainage ditches, onto open urban spaces and into inland waters, estuaries and the sea, causing severe stress on ground water sources resulting in environmental degradation through water pollution, serious health impacts, eye and nose sores and general compromise of sustainable development.

According to Ingallinela et al (2002), fecal sludge (FS) collected from on-site sanitation systems are usually discharged untreated into the urban and peri-urban environment, posing great risks to water resources and to public health. Strategies to cope with FS, adapted to the prevailing conditions in developing countries, have long been neglected. Kenya is not any different with the bulk of its cities and towns missing in trunk sewer infrastructure provision which is dependent on the Local Authorities (now County Governments) ability to provide this service.

According to the Kenya Environmental Sanitation and Hygiene Policy 2016-2030, about 12\% of the urban population use sewerage services and only 5\% of it is effectively treated Gakubia et al (2010). This means that most County Governments lack access to any form of sewerage system and are therefore highly exposed to environmental degradation. The Demographic Health Survey indicates that only $2.5 \%$ of the urban population had access to private (ownhousehold) improved sanitation in 2014. This is against a background of urbanization growth rates projected to reach $38 \%$ by 2030 , World Bank (2016) up from $8 \%$ at independence in $1963 \mathrm{GoK}$, (2009).There are conflicting statistics on access to and coverage of sanitation with the Joint Monitoring Programme (2015) placing access to improved sanitation in Kenya at 31\% while coverage is at $43 \%$ as classified by the United Nations (UN) and $12 \%$ according to Gakubia et al (2010). He notes further that less than $20 \%$ of the poor urban settlements have access to sanitation with $80 \%$ of facilities being shallow pit latrines which pollute the environment. (Water org/country/Kenya/1) 28 million Kenyans lack sanitation services while sanitation conditions are worst in the slum environments in which $50 \%$ of the urban population resides. By 2016, sewerage coverage in Kenya stood at $15 \%$ with a declining trend from $19 \%$ in 2010, Impact, (2016). Statistics emanating from Kenya are indicative of deplorable sanitation conditions.

\section{OBJECTIVE OF THE STUDY}

The objective of the study was to appraise the existing policies, legal and institutional frameworks and their influence in promoting sustainable sanitation management.

\section{LITERATURE REVIEW}

Literature available on policy and institutional frameworks is indicative of studies which have been conducted globally and regionally with studies in South America, Asia, Middle East and North African Region (MENA), West Africa, and the East African region. The studies have focused on various areas such as governance and sustainability in water and sanitation 
management Alejandro et al (2012) and Peters (2006), institutional analysis for water resource management in a river basin context Bandaragoda (2000), impact of institutional frameworks on private sector participation in water supply and sanitation Steiner et al (2008), comparative studies assessing sanitation and hygiene policies and institutional frameworks in Rwanda, Uganda and Tanzania, Ekane et al (2016),water catchment implementation in River Rwizi in Uganda Songa et al (2015), and an overview of legal and institutional frameworks for sanitation, Sathyanarayana (2017).

Environmental sanitation in Kumasi Acheampong (2010); private sector participation in water supply and sanitation with Jordan as a case study Steiner et al (2008) and reviews of the sanitation regulatory frameworks with particular attention to regulations on reuse of waste water and urban agriculture, Kvarnstrom et al (2005).

Studies conducted in Kenya have concentrated on sanitation in the peri urban areas, slums and informal settlements such as Moseti et al, (2009) on linkages between settlement profile and choice of sanitation systems in peri urban areas of Nakuru, Simiyu, (2017) on preference for and characteristics of an appropriate sanitation technology for slums in Kisumu, Muhele, (2016) on factors influencing sanitation practices in Kibera informal settlements in Nairobi, Omambia (2010) on perceptions, attitude and behavior in sanitation in Kibera slums and Kagwi (2010) on adequacy and efficiency of sanitation facilities for urban housing in Zimmerman area in Nairobi.

Studies with a bias to legal frameworks and governance in the water and sanitation sector are few such as efficacy of existing legislation and institutions in guiding development in a periurban area by Kakoi (2013) and governance of the water and sanitation sector Akech (2007). Whereas the study by Akech (2007) appraised the Water Act, 2002 and the associated institutional frameworks introduced by this law, many more reforms have since taken place in the water sector in Kenya. This study is one of the first to discuss comprehensively policies, legal and institutional frameworks and their contribution to sustainable sanitation management approaches in Mavoko municipality under the devolved system of government.

A review of relevant policies and legal frameworks existing in Kenya reveal that some policies have not taken an integrated approach to the management of the various sectors in the environment and especially in sanitation though most of them have incorporated public participation aspects. Sessional Paper No. 3 of 2004 on National Housing Policy, Sessional paper no. 3 of 2009 on National Land Policy, Sessional Paper No. 6 of 2012 on the Kenya Health Policy 2012, Environment Policy, 2013, Environment Sanitation and Health Policy (20162030), Sessional Paper No. 6 of 2016 on the National Urban Development Policy, 2016, Sessional paper no 1 of 2017 on National Land Use Policy, are considered.

Sessional Paper No. 3 of 2004 on National Housing Policy promotes low cost building materials and trunk infrastructure provision by the Local Authorities now turned County Governments however it is not aligned to the existing situation as it refers to nonexistent institutions. Sessional paper no. 3 of 2009 on National Land Policy recommends the resolution of land degradation through environmental management mechanisms such as environmental impact assessment (EIA) and audits (EA) highlighted in the Environment and Management Coordination Act thereby avoiding the duplication of effort.

Sessional Paper No. 6 of 2012 on the Kenya Health Policy 2012, identifies the need to create an enabling environment for increased private sector and community involvement in health services provision and finance while Environment Sanitation and Health Policy (2016-2030), 
enhances the existing legal and institutional framework to encourage active private sector, civil society and community participation in the planning, implementation and ownership of ESH services. The latter seems to imply a buildup of the enabling environment for private sector involvement but is not explicit.

The Environment Policy, 2013 provides for a framework of an integrated approach to planning and sustainable management of the environment and national resources and strengthens the legal and institutional framework for good governance, effective coordination and management of the environment and natural resources among others. Towards this end the National Environment and Management Authority is recognized by the policy as the requisite regulatory body. This policy is relatively comprehensive compared to all the policies formulated in the Country so far.

Sessional Paper No. 6 of 2016 on the National Urban Development Policy, 2016, envisions secure well governed competitive and sustainable urban areas through the facilitation of sustainable urbanization by delivering quality accessible and efficient infrastructure and services. The policy emphasizes plan formulation for the development of urban areas through investments in large scale infrastructure programmes. It notes the affected quality of air, water and land by contaminated water bodies and the degraded environment through pollution. It underscores the inadequate water and sanitation services, low investments in water and sanitation services and effluent discharge into natural water courses. It recommends the implementation of a legal framework that promotes equitable pricing of water and sanitation services, strengthening of the institutional capacity of the water and sanitation sector and promotion of water recycling.

The National Spatial Plan (NSP) (2016) notes the need for urban areas to be given attention with regard to provision of clean water and proper sanitation owing to the increase of urban population through rural urban migration. It lays emphasis on the expansion of sewerage systems especially in medium sized towns and municipalities of Chuka, Homabay, Kajiado, Mavoko, Naivasha and Wajir among others through the provision of centralized sewerage treatment system. It further advises for urban planning to make provisions for sewer systems and treatment works, adoption of appropriate technology to facilitate reduction, recycling and reuse of waste water, rehabilitation of storm water drainage systems and construction of waste water treatment plants. This is one of the policy documents that is alive to the need to maximize resource use however this is only advisory and its implementation is dependent on the Institutions charged with this mandate.

The Physical Planning Act (PPA) of 1996 provides for the preparation and implementation of physical development plans and for connected purposes. Section 24 (3) provides for preparation of a local physical development plan for the general purpose of guiding and cocoordinating development of infrastructural facilities and services for any urban area within the jurisdiction of a Local Authority now called County Governments. However the only existing comprehensive plan prepared for Mavoko municipality was prepared in 1970 implying that most of the development is taking place without a framework to guide, coordinate and harmonize development in the municipality. Consequently haphazard developments, urban sprawl, inadequate service provision and environmental degradation are likely leading to poor quality of life.

The County Government Act (CGA) and the Urban Areas and Cities Act (UACA) of 2012 and 2011 respectively fortify the requirement to have the urban areas and cities planned in order to enhance the management of the same. The CGA provides for county planning as a 
prerequisite to allocation and expenditure of public funding in the delivery of services. It devolves planning to the lowest administrative level by recognizing them as planning authorities. These are the county departments, city and urban areas sub counties, wards and villages. The aim of the plans prepared at these levels is to ensure integration, coordination and harmony of land use activities which are provided for in the fourth schedule of UACA. However these plans are not available and where found they are inadequate to afford development control and enforcement. Only the County Integrated Development Plans (CIDP) seem to have been prepared for most of the County Government due to the budgetary provisions which tie public spending to availability of this plan. The short coming of the CIDP is that it is biased to economic planning without a linkage to land on which most of the activities occur.

The Agriculture and Food Authority Act revised in 2015 provides for the regulation of agricultural activity in the protection of land against degradation and protection of water catchment areas in the interest of soil preservation and fertility. Part VI provides for County Governments to take care of all agricultural matters within their jurisdiction. They are expected to implement policy guidelines through legislation of county law, maintain uniformity and national standards in the agricultural matters in accordance with the national policy guidelines. There is no reference in the Act legislating on use of night soil (sanitized human waste) for enhancing soil fertility yet innovative solutions that treat and enable productive safe use of water and facilitate recovery of nutrients and organic matter from waste are booming Andersson et al (2018)

The Public Health Act (PHA) of 2012 provides for securing and maintaining health. It explicitly requires in Parts IX for the Local Authorities (County Governments) and Health Authorities to maintain clean and sanitary conditions in their jurisdictions and prevent all dangerous health conditions from inhabited dwellings, factory or trade premises respectively. Part XI provides for prevention of pollution of public water supply for domestic use and its purification by the County Government. This law details the protection of water supply but does not legislate on waste water. It only notes in section 118 (1) of types of nuisances such as cesspool, soak away pit, septic tanks among others which are likely to cause injury or dangerous to health.

The Subsidiary legislation to the PHA is more extensive and elaborates on the sanitary measures that may be taken by the Health Officer but only in the event of threats arising from the ports of entry into the Country. Public Health (Port, Airport and Frontier Health Rules, 1959 specifically section 15 empowers the Health Officer to take all practicable measures to control the discharge from any ship of sewage and refuse which might contaminate the waters of a port, river or canal. This is the best that the Law gets at with regard to human waste sanitation management as the rest of the rules compel the Health Officer to institute sanitary measures to passenger luggage, postal parcels and uncooked food stuffs at the Country's entry points.

The Irrigation Act, 1966, though provides for the development, control and improvement of irrigation schemes, and for purposes incidental thereto, it provides only for the establishment of the National Irrigation Board and mandates it in conjunction with the Water Resources Authority established under the Water Act (Cap. 372), to formulate, and be responsible for the execution of, policy in relation to national irrigation schemes; among other functions. The Irrigation Act though reviewed is not in tandem with the new developments that have taken place in the water sector from the enactment of the Water Act, 2002 to the Water Act 2016. The later responds to the recommendation by the NUDP to build the institutional capacity of 
the water and sanitation sector by providing for four Institutions at the National Government level namely Water Resources Authority, Water Harvesting and Storage Board, Water Services Regulatory Board and Water Sector Trust Fund. All these bodies have relevance to irrigation matters but their potential and importance has not been harnessed by the Irrigation Act, 1966 through the legislation of resource use maximization and reduction of waste.

Critical in delivery of water supply and sanitation services at the county level where municipalities fall, is the Water Services Regulatory Board (WASREB) whose major responsibility is to license conditions and accredit water services and develop a model memorandum and articles of association to be used by all water companies applying to be licensed by the Regulatory Board to operate as water services providers among other responsibilities. Mavoko Water and Sewerage Company (MAVWASCO) is the entity licensed by Tanathi Water Service Board (TWSB) which is one of the Boards under WASREB.

Environmental Management and Coordination Act (EMCA), 2018, provides for the establishment of an appropriate legal and institutional framework for the management of the environment. It establishes three institutions i.e National Environment Management Authority, County Environment Committee and National Environmental Tribunal. One of its major functions is to co-ordinate the various environmental management activities being undertaken by the lead agencies and promotes the integration of environmental considerations into development policies, plan, programmes and projects with a view to ensuring the proper management and rational utilization of environmental resources on a sustainable yield basis for the improvement of the quality of human.

EMCA, 2018 embellishes environmental planning; protection and conservation of the environment, environmental impact assessment (EIA), environmental audit and monitoring $(\mathrm{EA} / \mathrm{M})$ and outlines environmental offences. The regulations to this Act clarify the projects that must undergo an EIA. This Act compared to the other Acts on matters related to the environment is the most comprehensive and takes cognizance of most of the stakeholders with an influence on the environment. The penalties instituted by this Act impress upon offenders on the serious with which the offences are taken. Offender levies of Kenya shillings five million (Kshs 5,000,000/-) are made for polluting the environment against Kenya shillings one hundred thousand (Kshs 100,000/-) for offences related to the waste of groundwater and contamination and pollution of the same as provided by the Water Act, 2016. This is reflective of the mismatch still existing even after a review of most laws in the Country.

\section{STUDY AREA}

Mavoko Municipality in Machakos County in Kenya (Figure I) is situated in Eastern, Kenya, about $28 \mathrm{~km}$ from the Nairobi. Its geographical coordinates are $1^{\circ} 27^{\prime} 0^{\prime \prime}$ South, $36^{\circ} 59^{\prime} \quad 0$ " East and its original name is Athi River. This is the area under the administrative boundary of Mavoko Municipality also known as Mavoko Sub County and covers an area of $963 \mathrm{~km} 2$ according to the spatial planning concept for the Nairobi Metropolitan Region (2013). It falls under the Mavoko Constituency area which comprises four wards made up of Athi River, Kinanie, Muthwani and Syokimau/Mlolongo, Independent Electoral Boundaries Commission (2015). Settlements within the study area comprise both standalone houses (SAs) and comprehensive housing schemes (CHSs). SAs are individual housing units occupying a distinct parcel of land with own or private entrance whilst the CHSs are many housing units with similar design, on a common parcel of land and constructed by a common developer. They share a secured common entrance and are confined within a gated community. CHSs are unique as they concentrate populations of over 300 households on land parcels ranging from 1 acre to 5 acres of land. 


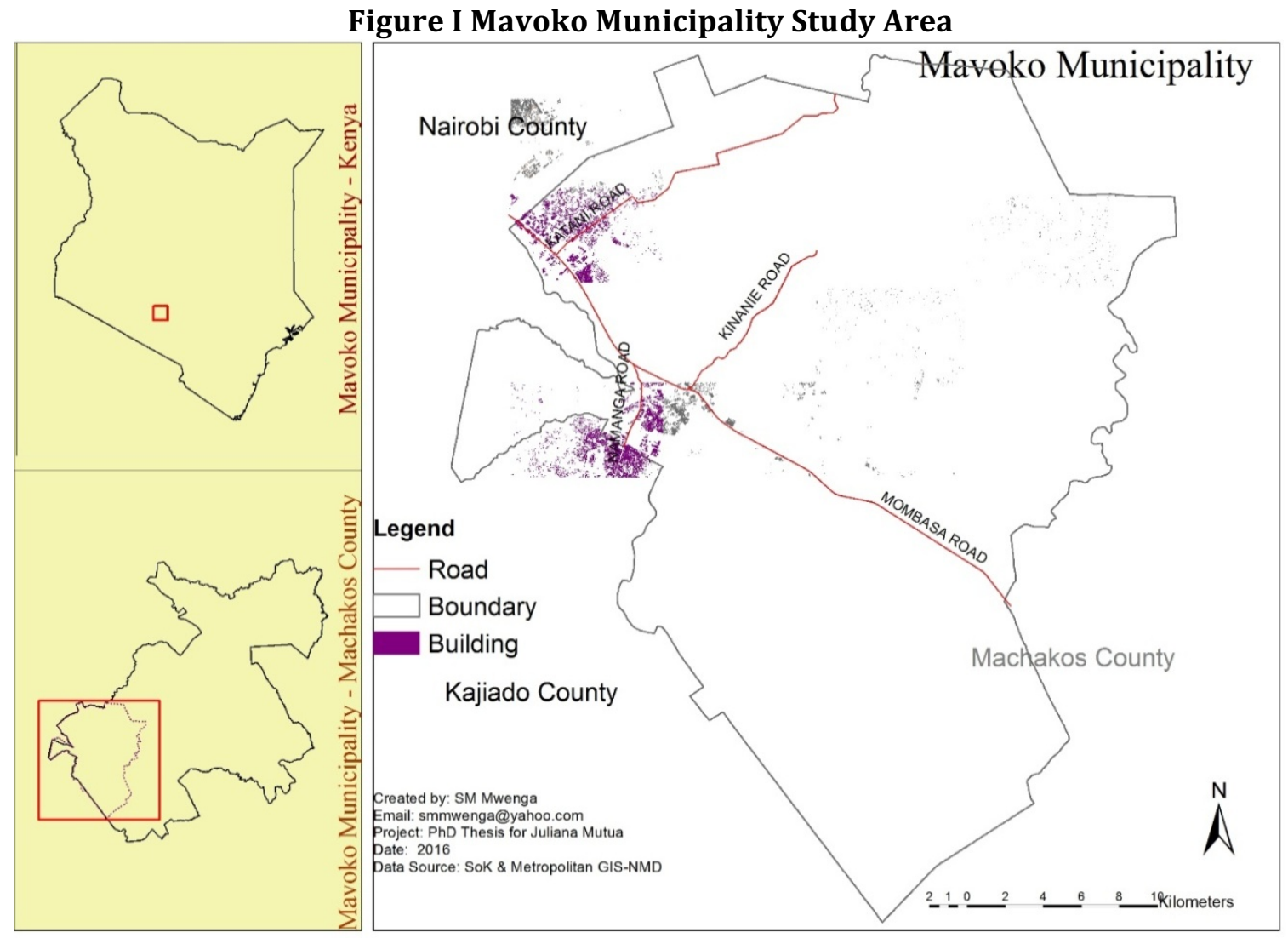

Source: Nairobi Metropolitan Department, 2015

\section{RESEARCH DESIGN AND METHODOLOGY}

A cross sectional study design was chosen as it was best suited in establishing an overall picture of study as it stands at the time Kumar (2005). It involved collection of primary data from respondents from a select sample from the study population which had already been identified as Mavoko Municipality. Assuming a 95\% confidence level with a $Z^{*}$-score value of 1.96, standard deviation of 0.5 and a margin of error of 0.5 ,Israel (2013) hence the formula:-

$$
n_{0}=\frac{Z^{2} p q}{e^{2}}
$$

Where $\mathrm{n}_{\mathrm{o}}$ is the sample size

$\mathrm{Z}^{2}$ is $1.96^{2}$

$\mathrm{e}^{2}$ is $0.05^{2}$

$\mathrm{p}$ is 0.5

$\mathrm{q}$ is 0.5

Though the calculated sample arrived at was 384.16, a sample of 385 was used. This sample size was further rechecked using Ghooyt's (1994) and Krejcie and Morgan (1970) recommended guidelines to sample size of 244259 people which fell in the bracket of 1000000 with a same sample size 384. 96 and289 questionnaires were administered to standalone and comprehensive households using the ratio of 1:4 as informed by Mugenda (2011). Random sampling was used to administer questionnaires to standalone houses which were homogenous in characteristic and because the design afforded an opportunity to each of the samples to be interviewed. Kothari (2004) 


\section{Method Used To Collect Data}

To ensure that bias was minimized and that each part of the study area had an equal probability of being sampled, the area populations for each of the wards which make up Mavoko Municipality were used to come up with ratios which guided the apportioning of questionnaires into the stand alone and comprehensive housing schemes.

Table I Ratio for apportioning questionnaire administration by Wards

\begin{tabular}{lccc}
\hline Ward & Population & $\begin{array}{c}\text { Ratio (Ward } \\
\text { Population/Total Population } \\
\text { of Study Area) }\end{array}$ & $\begin{array}{c}\text { Questionnaires } \\
\text { for administration }\end{array}$ \\
\hline Athi River & 139,502 & $139,502 / 244,259=57$ & 219 \\
Kinanie & 7,069 & $7,069 / 244,259=3$ & 12 \\
Syokimau & 42,154 & $42,154 / 244,259=17$ & 66 \\
Katani & 55,534 & $55,534 / 244,259=23$ & 88 \\
\hline Total & $\mathbf{2 4 4 , 2 5 9}$ & $\mathbf{5 7 : 3 : 1 7 : 2 3 = 1 0 0}$ & $\mathbf{3 8 5}$ \\
\hline
\end{tabular}

Source: Author, 2015

Purposive sampling method was used to allow the Researchers to make their own judgment as regards the best source of information that is sought, Kumar, (2005). In this case purposive sampling was used to identify a new phenomenon of comprehensive housing schemes of developments with a common developer though developed at various periods in time. The schemes developed earlier were bound to have tenants/owners who had occupied the houses for longer periods and therefore likely to have had more exposure to sanitation study concerns.

Since they made up part of the total population of households in the study, a proportion of the questionnaires were shared amongst comprehensive housing schemes ${ }^{1}$ and standalones $^{2}$ on a ratio of $1: 4$ on the assumption that the population sizes of the standalones far outnumber the comprehensive housing schemes which are a new development. Once more the ratios were allocated to each of the wards and final figures calculated.

Table II Apportioned questionnaires for administration by Household Type

\begin{tabular}{llcc}
\hline Ward & $\begin{array}{l}\text { Assumed ratio of standalone } \\
\text { houses to comprehensive } \\
\text { housing schemes is 1:3 based on } \\
\text { observation of the study area }\end{array}$ & $\begin{array}{l}\text { Final Questionnaires for } \\
\text { administration to stand alone (SA) } \\
\text { and Comprehensive Housing } \\
\text { Scheme (CHS) }\end{array}$ \\
SA & 165 & CHS \\
\hline Athi River & $(1 / 4)=0.25^{*} 219$ & 9 & 35 \\
Kinanie & $(1 / 4)=0.25 * 12$ & 50 & 16 \\
$\begin{array}{l}\text { Syokimau } \\
\text { Katani }\end{array}$ & $(1 / 4)=0.25 * 66$ & 66 & 22 \\
\hline $\begin{array}{l}\text { Sub-Total } \\
\text { Grand Total }\end{array}$ & & $\mathbf{2 9 0}$ & $\mathbf{3 6}$ \\
\hline
\end{tabular}

Source: Author, 2015

1 These are the many housing units with similar design, on a common parcel of land and constructed by a common developer. They share a secured common entrance and are confined within a gated community.

2 These are individual housing units occupying a distinct parcel of land with own or private entrance. 


\section{Data Analysis}

Primary data in the form of household questionnaire administration and interview of key informants were conducted with the county officials mandated by the various ministries such as environment and natural resource, water resources management, agriculture, livestock and fisheries, land and physical planning. Ministry of health, agriculture and transport, infrastructure, housing and urban development were interviewed too.

Key informants from other institutions in the study area like the Mavoko Water and Sewerage Company (MAVWASCO) water service provider and the Export Processing Zone Authority were interviewed too. Secondary data in the form of literature review on the policies, acts and institutional frameworks was used to support and link research findings with the existing body of knowledge.

Primary and secondary data gathered were analyzed using the social statistical package for social sciences (SPSS) version 23 and descriptive statistics presented by way of tables, graphs, frequencies and percentages. A content analysis was used to develop thematic issues discussed in the paper.

\section{RESULTS}

\section{Sanitation Management Approaches Used In Mavoko Municipality}

Types of sanitation method used were presented relative to their location, (see table III) though Athi River area has the largest urban population, less than $40 \%$ of this population is served with the conventional sewer line .Katani and Syokimau areas trail at less than 14\% on use of the conventional sewer. However these areas have common user septic tanks whose residents confuse with a conventional sewer system. The septic tank is in high use in the Sabaki area ranked at $83 \%$ of the population using the sanitation approach. Mlolongo and Syokimau follow at $68 \%$ and $64 \%$ respectively.

The simple latrine is in greatest use in Kinanie rated at 93\%. Other sanitation management approaches in use are the pour flush latrine highly used in Athi River ward compared to other areas. However it comes fourth in line among the sanitation management approaches within Athi River ward i.e. after conventional, septic tank and simple latrine at 36\%, 23\% and 20\% respectively.

Table III Type of Sanitation Method Used and Location

\begin{tabular}{lccccccc}
\hline $\begin{array}{l}\text { Sanitation } \\
\text { Method Used }\end{array}$ & Athi River & Katani & Kinanie & Sabaki & Mlolongo & Syokimau & Total \\
\hline $\begin{array}{l}\text { Conventional } \\
\text { sewer }\end{array}$ & 36.5 & 13.1 & 0 & 8.3 & 4.5 & 10 & 23.9 \\
$\begin{array}{l}\text { Small bore } \\
\text { sewer }\end{array}$ & 5.4 & 2.4 & 0 & 0 & 9.1 & 4 & 4.4 \\
Septic tank & 23.6 & 42.9 & 7.1 & 83.3 & 68.2 & 64 & 36.9 \\
Pour flush & 12.3 & 0 & 0 & 0 & 9.1 & 0 & 7 \\
latrine & 1.5 & 7.1 & 0.0 & 0.0 & 0.0 & 4.0 & 2.9 \\
VIP latrine & 20.2 & 34.5 & 92.9 & 8.3 & 9.1 & 12.0 & 23.9 \\
Simple latrine & 0 & 0.0 & 0.0 & 0.0 & 0.0 & 6.0 & 0.8 \\
Bio digester & 0.5 & 0.0 & 0.0 & 0.0 & 0.0 & 0.0 & 0.3 \\
Cess pit & & $50 u r c t$ & & & & & \\
\end{tabular}

Source: Field Survey, 2016 


\section{Sanitation Management Approach in Standalone Housing and Comprehensive Housing}

\section{Schemes}

Compared between the stand alone and comprehensive housing schemes it was found that there was no marked difference in the use of sanitation management approaches. Table IV shows that all house types returned similar results in the use of the septic and conventional sewer systems as the first and second modes of sanitation management at $48 \%$ for CHS and $33 \%$ for SA. The pit latrine is commonly used by the SA and is highest at $30 \%$ compared to the CHS at only $7 \%$.

Table IV Type of Sanitation Method Used and Household Type

\section{\% Household Type}

\begin{tabular}{lcc} 
Sanitation Method Used & $\begin{array}{c}\text { Stand Alone } \\
\text { Houses (SA) }\end{array}$ & $\begin{array}{c}\text { Comprehensive } \\
\text { Housing Scheme (CHS) }\end{array}$ \\
\hline Conventional sewer & 24.0 & 23.7 \\
Small bore sewer & 0.3 & 17.2 \\
Septic tank & 33.2 & 48.4 \\
Pour flush latrine & 9.2 & 0.0 \\
VIP latrine & 2.4 & 4.3 \\
Simple latrine & 29.5 & 6.5 \\
Bio digester & 1.0 & 0.0 \\
Cess pit & 0.3 & 0.0 \\
\hline
\end{tabular}

Source: Field Survey, 2016

\section{Role of Residents in Formulation of Policy and Laws}

Most of the Citizens did not play any role in influencing the formulation and amendment of laws and regulations. Figure II shows that $90 \%$ of the respondents reported not influencing laws formulation while only $6 \%$ indicated influencing the same.

Figure II Respondents Influence in Formulation and Amendment of Laws and Regulations

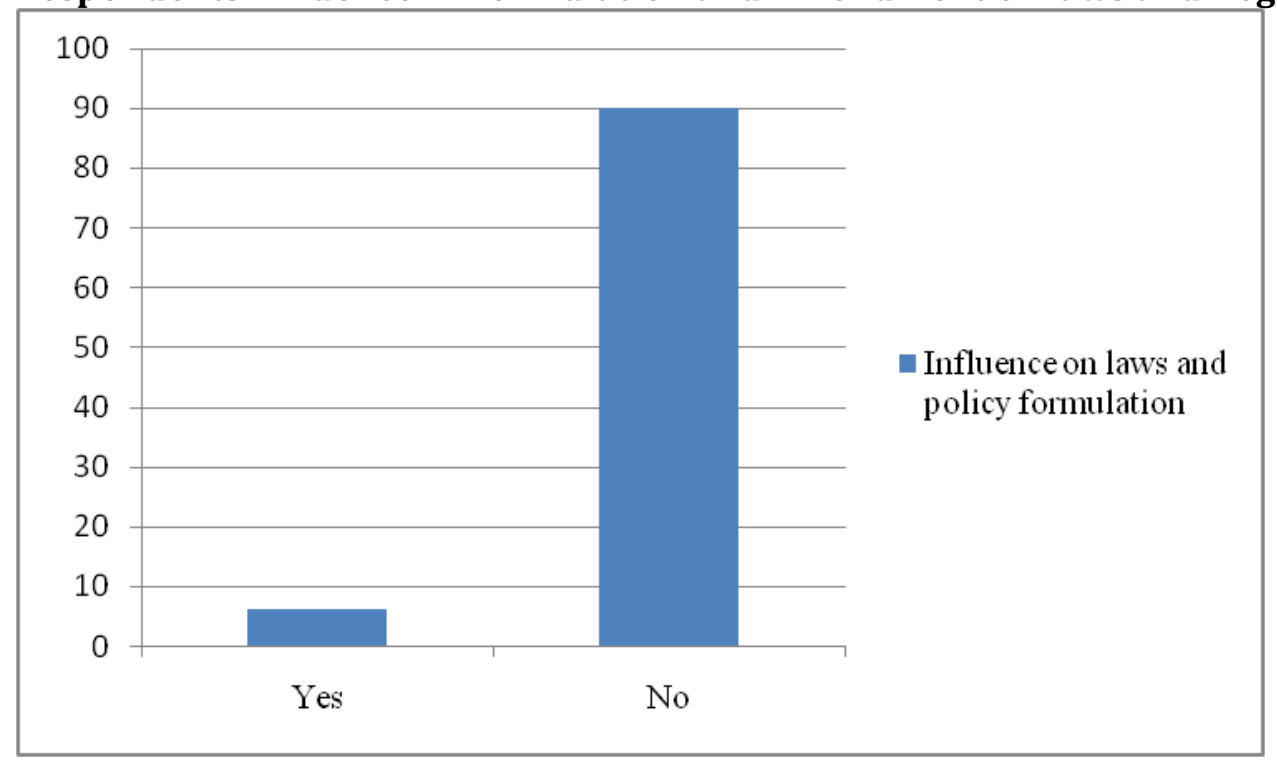

Source: Field Survey, 2016

Figure II shows that of the $6 \%$ of the respondents who indicated influencing laws and regulations, $3 \%$ said that they did this through participation in stakeholder forums. Less than $1 \%$ was sensitizing fellow residents on good sanitation practices. Other methods of involvement included complying with the set rules and regulations, voting and reporting problems to the relevant authorities which were similarly less than $1 \%$. 


\section{Figure III Respondents Role in Influencing Formation and Amendment of Laws and Regulations}

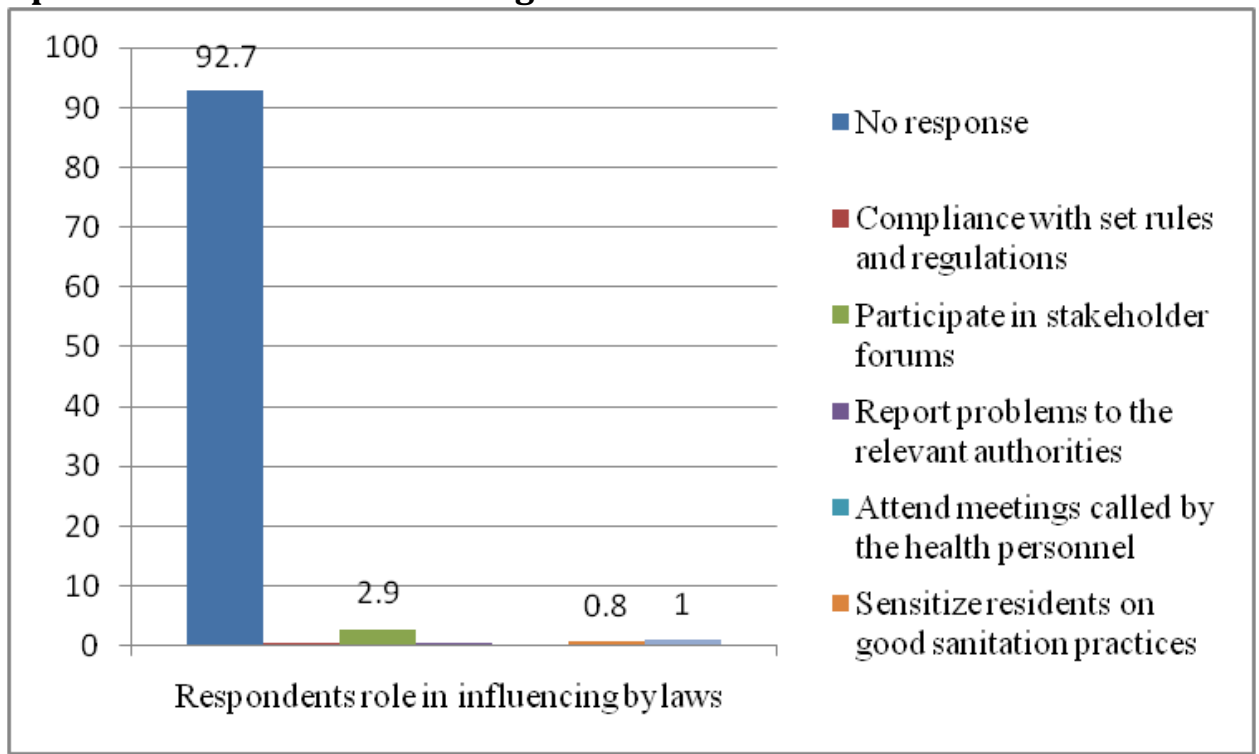

Source: Field Survey, 2016

\section{Respondents' Awareness of Policies}

$58 \%$ of respondents were aware of the environment policy while $35 \%$ and $27 \%$ were aware of environment sanitation and health and health policies respectively. Awareness on housing and land policies were recorded both at 13\%. National Urban development policy was the least known with $13 \%$ of the respondents indicating awareness. Figure IV illustrates Respondents levels of awareness.

Figure IV Respondents Awareness of Policy

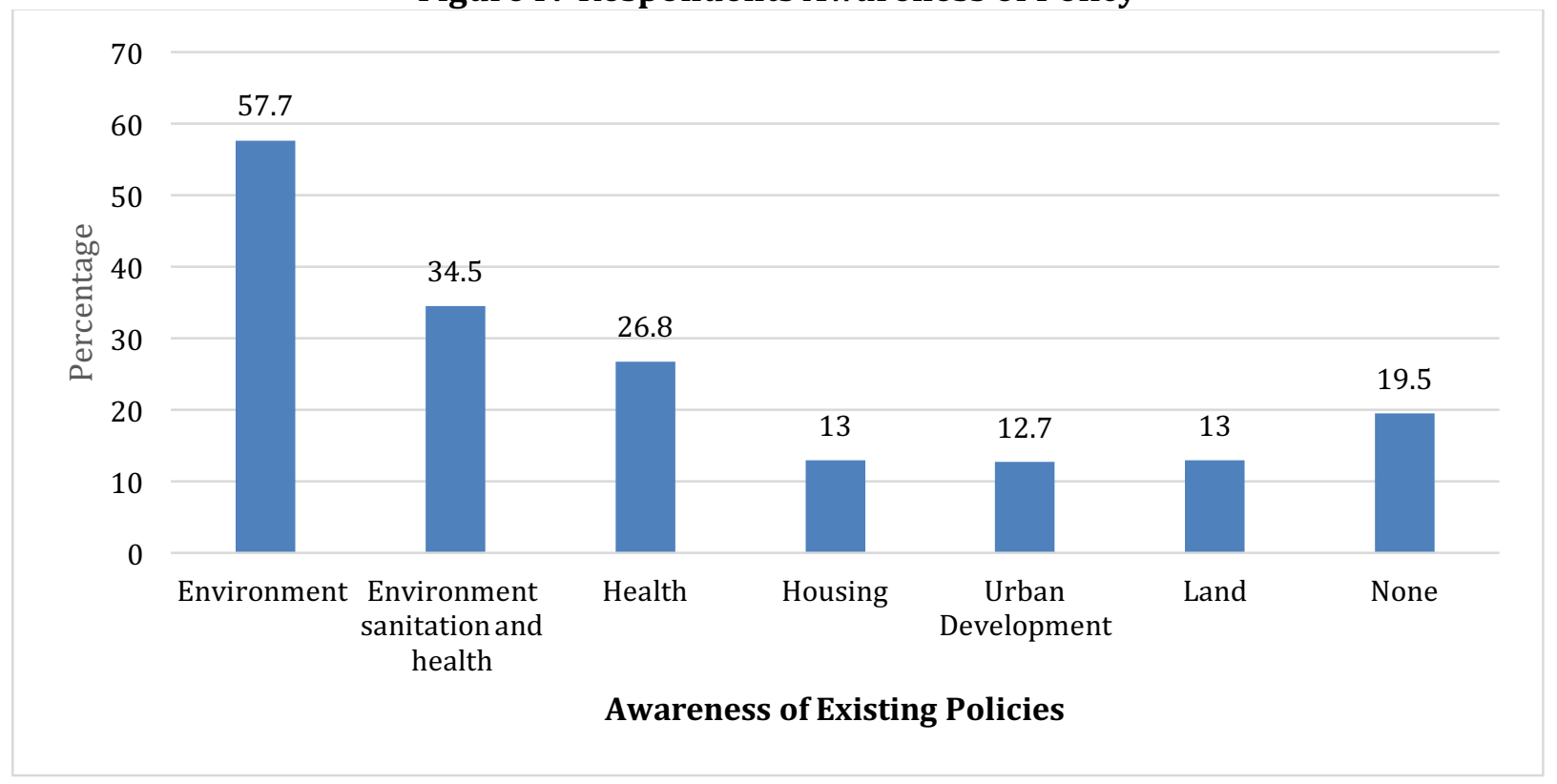

Source: Field Survey, 2016

\section{Respondents' Compliance with Laws}

Figure V illustrates Respondents Compliance levels with various laws that should be implemented and enforced by the County Government of Machakos in which the Mavoko municipality falls. Public Health Act is the most known law with $32 \%$ of the respondents indicating their awareness about it. Environment and Management Act was second with 28\% of the respondents registering their awareness on it. County Government Act and the Land Act 
came third and fourth at $21 \%$ and 19\% respectively. Agriculture Act was the least known at $1 \%$ most likely because the study area comprised an urban population. Urban Areas and Cities Act tallied with $5 \%$ of the Respondents indicating their awareness. This low rate of awareness may be attributed to its recent enactment in 2013.

Figure V Respondents Compliance with Laws

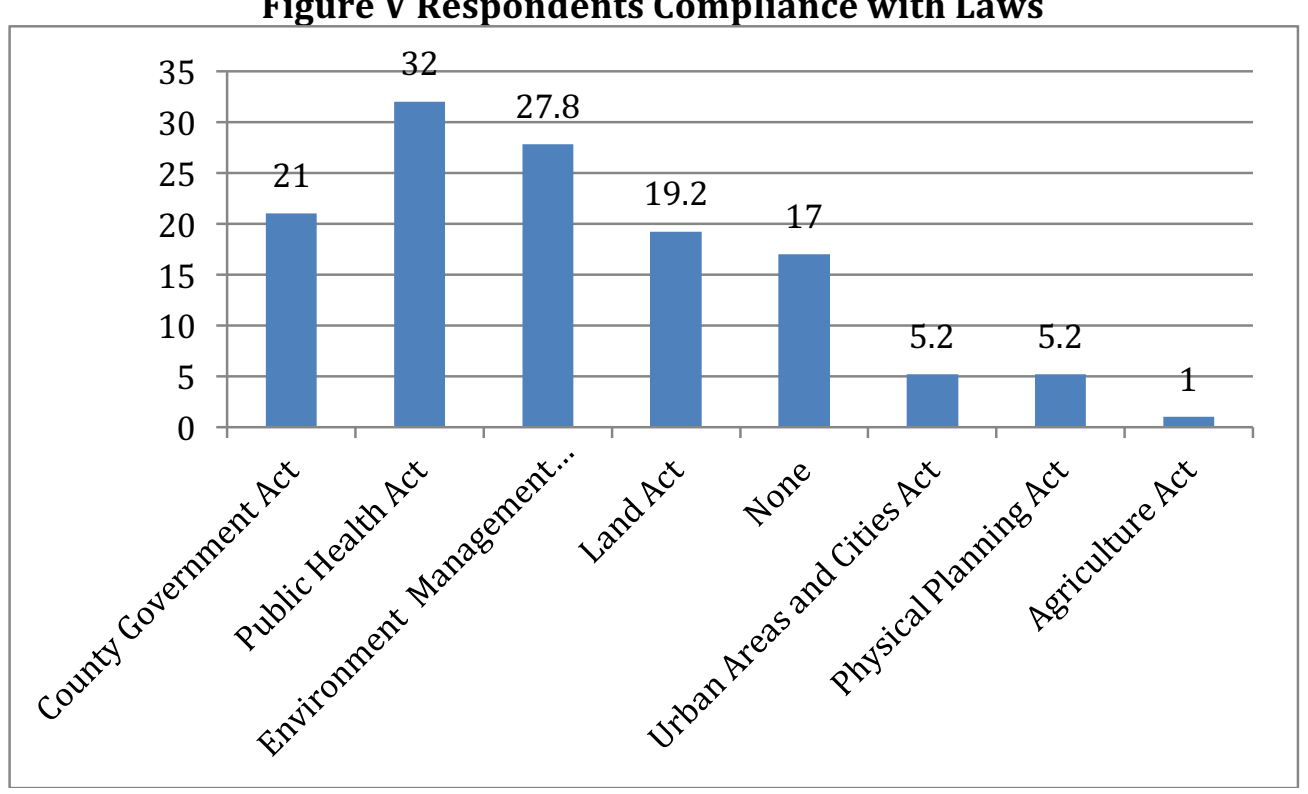

Source: Field Survey, 2016

\section{Institutions Active in Sanitation Management in the Municipality}

Figure VI illustrates that the County Government was rated as the most active in relation to sanitation management activities at 44\%. Other institutions in the form of Developers, Donor Agencies, and Non-Governmental Organizations were rated at less than 15\%. However there were respondents who indicated that none of the mentioned Institutions were active in the study area and this made up for $24 \%$ while those who did not give any response were $16 \%$

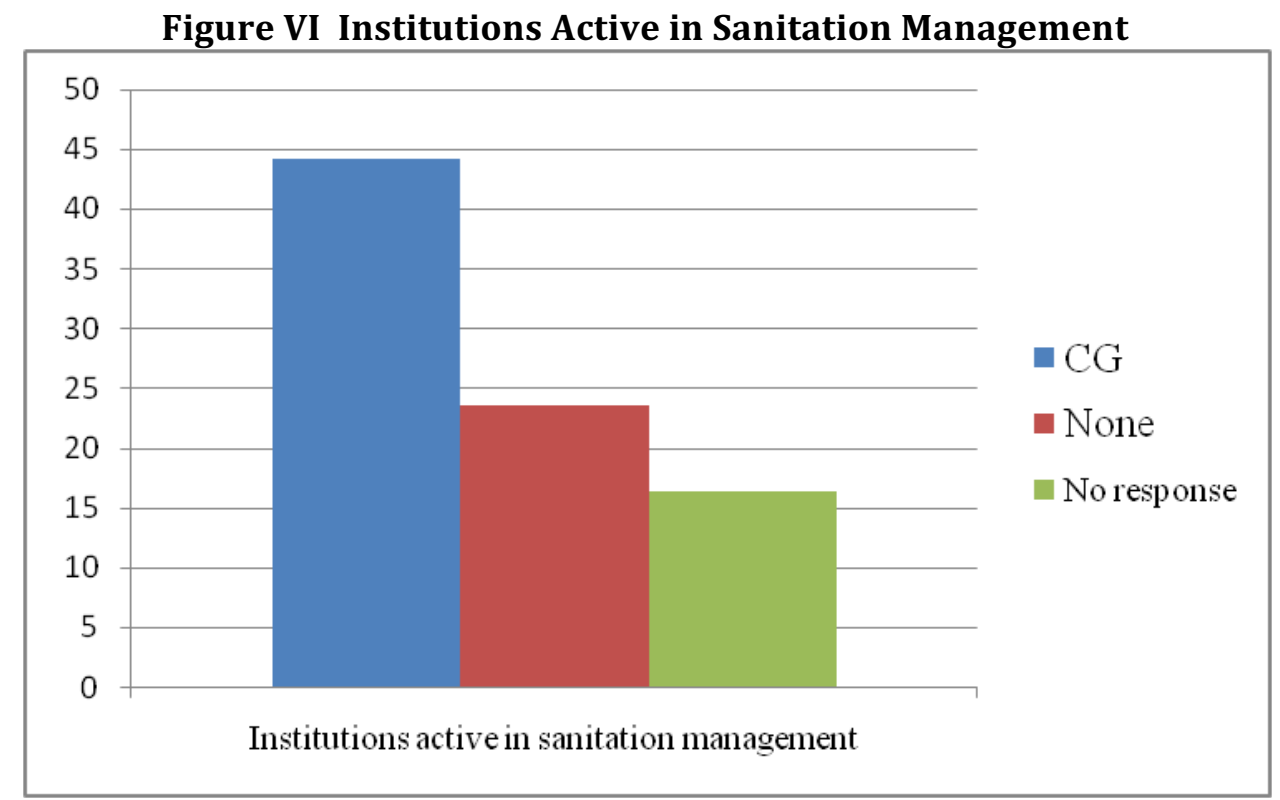

Source: Field Survey, 2016

On triangulation of the information to establish availability of other Institutions existing in the study area, records available from the Social District Development Office were only reflective 
of self-help groups concerned with persons living with disability, vulnerable groups' i.e. women, youth and the orphaned and whose agenda was not related to sanitation management.

There was an only self-help group known as the Enterprise Self Help Group in Katani which fell under an umbrella body known as the 'Paul Mue Foundation'. Among the fourteen objectives it has, improved latrines and provision of sustainable sanitation was the last indicating the least prioritization being accorded to the sector. A close follow up on the SHG did not yield additional information as a promise to return a call by the contact person was never fulfilled nor was there any physical address to afford visits to the Organization.

The study established Syokimau Residents Association as the only existing Residential Neighbourhood Association (RNA). It was active in the urbanizing areas of Syokimau and neighbouring Katani area in Mavoko Municipality. The RNA has been active in enforcing proper environmental management. It has engaged NEMA and successfully sued a Developer whose faulty septic tank has been discharging raw sewage into the Sabaki stream. It has obtained a Court order stopping Contractors from further developments until they unblock the Sabaki stream. MAVWASCO and Export Processing Zone Authority (EPZA) were not mentioned among the Institutions providing services in the area.

Table $\mathrm{V}$ on involvement of Institutions in sanitation matters shows that $54 \%$ of the respondents did not respond to this question. Only 29\% of the respondents indicated involvement of Institutions mentioned as active, in providing drainage and sewerage services. Maintenance of the sewer line and provision of water services were other activities undertaken by the Institutions but with only $5 \%$ and $4 \%$ of the respondents acknowledging this. Sensitization and awareness creation in sanitation matters, enforcement of sanitary laws and provision of exhauster services were below $3 \%$.

Table V Involvement of Institutions in Sanitation Management

\begin{tabular}{lc}
\hline Areas of Involvement by Institutions & $\mathbf{\%}$ \\
\hline Provide drainage and sewerage services & 29.1 \\
Maintenance and repair of sewer system & 4.9 \\
Ensures sanitary laws are implemented & 1.3 \\
Sensitizing and educating public on sanitation matters & 2.3 \\
Provision of water services & 3.9 \\
Provision of public toilets & .3 \\
Provision of exhauster vehicles & 1.3 \\
Clean up exercises by NGOs & .5 \\
Garbage collection & 1.6 \\
Sensitize on agriculture matters & .3 \\
None & .5 \\
No response & 54.0 \\
\hline
\end{tabular}

Source: Field Survey, 2016

\section{Institutional Challenges}

There were conflicting responsibilities as practiced by both the Export Processing Zone Authority (EPZA) and MAVWASCO. According to the Export Processing Zone Act Cap 517, the Export Processing Zone Authority (EPZA) was established to provide for the promotion and facilitation of export oriented investments and the development of enabling environment for such investment and for connected purposes. It has as one of its objectives, the development of all aspects of the export processing zones with particular emphasis on provision of advice on 
the removal of impediments to, and creation of incentives for, export-oriented production in areas designated as export processing zones provided in section 9 (1) (a).

To carry out this function, it is further provided in section 2(d) to plan the development and maintenance, and to finance the basic infrastructure up to the perimeter of the export processing zones. EPZA is involved in sanitation management because of the interest of providing incentives to Investors. EPZA has invested in a sewer line that runs from its parcel of land on the boundary of Mavoko and Kajiado Counties through the Athi River Municipality towards Kinanie area which hosts the oxidation ponds.

MAVWASCO on the other hand was established in 2006 as a limited liability company under the water sector reforms enshrined in the Water Act 2002 (Mavoko Water Strategic Plan 2016). It is mandated to provide water service provision in its area of jurisdiction by a Service Provision Agreement (SPA) and license from Tanathi Water Service Board (TWSB). According to the EPZA Officer in charge of the water sector, in 2002 when the water reforms were introduced through the Water Act, MAVWASCO and EPZA entered into a merger and formed the Mavoko EPZA Water and Sewerage Company in November 2006. The aim was to ensure that surplus water which EPZA had sourced and invested in from Nairobi was sold to MAVWASCO.

However the merger collapsed in November 2007 due to 'irreconcilable differences'. MAVWASCO wanted all the bulk water supply from EPZA without giving an assurance that they would supply water to EPZA Investors on a 24 hour basis. It claims the assets put in place by the EPZA on grounds that they have the mandate to supply water to Consumers in Mavoko municipality and Kitengela town through the license from TWSB, claims the infrastructure passes through its 'ancestral land', refuses to pay sewer revenue to EPZA and wants staff of EPZA dealing with water and sewerage services laid off.

At the County and National government levels, Key Informants that is the County Physical Planner, County Environment Officer, County Public Health Officer, County Water Officer and the County Public Officers all complained of difficulty in enforcing the prevailing laws and regulations due to low personnel capacity, inadequate facilitation and transport logistics to field visits and poor monitoring as a result of non-adoption of new technologies to aid work. Inadequate investment in sewerage infrastructure kept on recurring with all Key Informants emphasizing it.

\section{Role of Machakos County Assembly in Sanitation Management Affairs}

Mavoko Municipality comprises of four Wards namely Athi River, Kinanie, Syokimau and Katani and are represented in the County Assembly of Machakos. The latter consists of all Ward Representatives elected by registered voters of the Wards for a five year term. The Assembly is empowered by Article 185 of the CoK, 2010 to legislate on matters of the County, have oversight over the County Executive Committee and any other County organ, receive and approve plans for management and exploitation of county resources and the development and management of its infrastructure and institutions.

It is specifically assigned the functions of county water and sanitation services among other services. Part two of the fourth schedule of the CoK, 2010 further provides in 11 and 14 for Counties to assist communities and locations to develop the administrative capacity for the effective exercise of the functions, powers and participation in governance at the local level. 
The deliberations of the Machakos County Assembly Select Committee on Environment, Land, Energy and Natural Resources whose term ran from 2013 to 2017 were analyzed to establish the involvement of the County Legislative Arm in addressing sanitation management matters. Some of its mandates were to deal with matters related to the implementation of specific National Government policies on natural resources and environmental conservation, including soil and water conservation and forestry, control of air pollution, noise pollution, water management systems in built up areas and water sanitation services.

Debate in the life of the Assembly indicates that out of the 19 bills that were discussed, 9 became Acts of the Assembly but none dealt with the subject of sanitation management, Kenya Law, (2016).Similarly out of total allocation funds amounting to Kenya Shillings ten billion, eight seventy six million (Kshs. 10,876,000,000/-),allocations made to recurrent and development portfolios of sanitation and solid waste management respectively, illustrate that they got Kenya shillings sixty nine million, eight hundred and seventy thousand (Kshs.) $69,870,000 /-$ and fifty one million, five forty two thousand seven hundred and twenty Kshs. $51,542,720 /$-amounting to $0.006 \%$ and $0.005 \%$ of the total budget. Machakos County Appropriation Act No. 3, (2016)

These allocations were the second least funded with only the portfolio on 'General Administration and Support Services, ICT Infrastructure, Information and Communication Technology, and Human Resource Management and Development of Public Service, Labour and Information Communication and Technology being at the bottom of the rank with allocations of Kenya Shillings forty eight million three thirty three thousand one hundred and six only (Kshs. 48,333,106/-).

Compare this further to Kenya Shillings four hundred sixty three million, one hundred and twelve thousand one hundred and seventy (Kshs.463,112,170/-) and Kenya shillings two hundred and fifty nine million, three hundred ninety six thousand four hundred and seventy three (Kshs.259,396,473/-) recurrent funds allocated to the Committees on 'General Administration and Support Services, Crop Development and Management, Development, Fisheries, Veterinary, Development of Agriculture, Livestock, Lands and Urban Development and General Administration and Support Services, Road Maintenance and Management, County Transport and Management and Infrastructure Development, Housing Development and Human Settlement, and County Government Buildings of Transport, Roads, Public Works and Housing Machakos County Appropriation Act, (2016)

\section{DISCUSSION}

According to the results sanitation management approaches in use are mainly conventional sewer system and on site sanitation management methods of septic tanks and simple pit latrine type with majority relying on the latter two. This is consistent with the findings of Ingallinela et al (2002), Murray (2012), Tilman et al (2015) that majority urban dwellers rely on onsite sanitation systems. Onsite sanitation management approaches face challenges of safe disposal of effluent and especially in areas challenged by land topography, soil type and vulnerability to flooding Tumwebaze et al (2011) -conditions which are prevalent in Mavoko municipality as a result of the existence of the black cotton soils which are a characteristic of climate which is seasonally humid or subject to erratic droughts and floods due to impeded drainage. These soils have the characteristics of high swelling and shrinking when exposed to changes in moisture content Gaikwad et al (2014).

The results found that there were low levels of involvement and compliance of Residents of Mavoko Municipality with regard to formulating policy and laws, implementing and enforcing 
them. This is in agreement with Chirenje et al (2013) who asserts that policy and development which adopt a bottom up approach framework where local communities are actively involved in decision making better facilitate the achievement of target objectives. It also corroborates Olukanni et al (2014) finding that lack of connection between Institutional policies and the peoples' sanitation practices challenged efforts made towards the attainment of the millennium development goals which have now been refocused as the sustainable development goals. It is emboldened by Michels et al (2010) who notes the need for early involvement of stakeholders for greater support of government policy, effectiveness and legitimacy.

Institutional challenges in overlap of mandates, poor representation of sanitation matters by Machakos County Assembly and low budgetary provisions for the sector are other findings of the study. Institutional challenges of mandate overlap are consistent with Sathyanarayana (2017) who identifies lack of clear delineation of responsibilities as a challenge to institutional frameworks while IEES (2018) stress the need to outline the responsibilities of services for various aspects of water and sanitation sectors as a precondition for successful implementation of other sanitation and water management interventions.

The findings of Residents low awareness with sanitation policy and laws alludes to the poor enforcement and non compliance of the same. This suggests the poor performance of Institutions responsible for sanitation management and specifically the County Government of Machakos. It is indicative of the failure by the County Government to harness the potential in effective contractual relationships that have been shown by Water and Sanitation Program (2011) and partnerships between municipalities and providers, Jones et al (2006) to provide flexible entry for the private sector and NGOs in sanitation promotion, investment and delivery. It is similarly in support of Okumu and Osterveer (2010) argument that Local Authorities are unable to put in place alternative plans and regulations for physical environmental infrastructure development. It affirms Aketch's (2007) observation that institutional frameworks were neither effective nor accountable in governing water and sanitation in Kenya.

Poor representation of sanitation matters by the legislative arm of Government and by extension political leadership has been found to impede progress in the improvement of sanitation management. The dismal allocations in the sanitation sector which is not even accorded a line item and is a public service good in the form of health and environmental externalities which according to Balasubramanya et al (2017) deserves a subsidy avers Cronin (2015) pronouncement that political will as one of the components of political factors and support from high profile champions can help prioritize and initiate momentum, in moving the sanitation agenda forward.

\section{CONCLUSION AND RECOMMENDATIONS}

The objective of the study was to appraise the institutional frameworks and their influence on implementation of the existing policies and legal frameworks in sanitation management. The results revealed that onsite sanitation management approaches commonly used in Mavoko municipality coupled with the low levels of Residents awareness with prevailing policies and laws and poor involvement in sanitation matters was a challenge to proper sanitation management. Institutional overlaps between EPZA and MAVWASCO were compromising service delivery to Mavoko municipality Residents. The depressing budgetary allocations were hindering the promotion of the sanitation sector. Consequently Institutions for sanitation management have not performed well in promoting sustainable sanitation management approaches. 
The National Government (NG) and the County Government of Machakos (CGM) need to clarify the mandates of EPZA and MAVWASCO to curtail the differences existing between the two service providers. CGM should identify champions for the sanitation sector and increase budgetary allocations to facilitate investments in the sector while ensuring that Residents of Mavoko Municipality are constantly reminded about the legal provisions and requirements for proper sanitation management to raise their levels of awareness and compliance with the same for sustainable development.

\section{References}

Acheampong, P.T (2010) Environmental sanitation management in the Kumasi metropolitan area.. Unpublished MSc thesis Kwame Nkrumah University of Science and Technology pp 1-100

Agriculture and Food Authority Act No 13 (2013). Revised edition (pp. 1-46). National Council for Law Reporting.

Aketch, M.J.M (2007) 'Governing Water and Sanitation in Kenya: Public law, Private Sector Participation and the Elusive Quest for a Suitable Institutional Framework' Paper prepared for the workshop titled Legal Aspects of Water Sector Reforms in Geneva 20-21st April, 2007. International Environmental Law Research Centre (IELRC) in the context of research partnership 2006-2009 on Water Law sponsored by the Swiss National Science Foundation.

Alejandro, M, Garay, I and Seghezzo, L (2012) Governance, sustainability and decision making in water and sanitation management systems. Sustainability vo4,2922-2945 doi 10:3390/su4112922

Andersson, K, Otoo, M, and Nolasco, M (2018) Innovative sanitation approaches could address multiple development challenges. Water, Science and Technology 77(4) pp 855-858

Balasubramanya, S, Evans B, Hardy, R, Ahmed, R, Habib, A, Asad, N.S.M, Rahman, M, Dey, D, Fletcher, L, ValeroCamargo, M.A, Rao, J.C and Fernando, S(2017) Towards Sustainable sanitation management: Establishing the costs and willingness to pay for emptying and transporting sludge in rural districts with high rates of access to latrines.PLoSONE 12(3): pp 1-20 e0171735.https://doi.org/10.1371/journal.pone.0171735

Bandaragoda, D.J (2000) A framework for institutional analysis for water resources management in a river basin. International Water Management Institute Working Paper no 5 pp -43

Chirenje, L, Giliba, R,A and Musamba, E,B (2013) local communities participation in decision making processes through planning and budgeting in African Countries. Journal of population resources and environment vol 11 issue 1 pp 10-16

County Government Act (2012) pp 1-98 revised edition 2013 National Council for Law Reporting.

Cronin, A. A., Badloe, Chander, Torlesse, H., \& Nandy, R. K. (2015). Water Sanitation Hygiene Moving the Policy Agenda Forward in the Post 2015 Asia Asia and the Pacific Policy Studies, 2, 227-233.

https://doi.org/10.1002/app5.90

Ekane, N, Wectz, N, Nykvist,B, Nordquist, P and Noel Stacy (2016) Comparative assessment of sanitation and hygiene policies and institutional frameworks in Rwanda, Uganda and Tanzania Working Paper. Stockholm Environment Institute M.2016-05 pp1-29

Environmental Management and Coordination Act No. 8 of1999. (1999). pp. 1-51. National Council for LawReporting.

Export Processing Zone Authority Act Cap 517 (1990)

Gaikwad, K.S, Ratan, P.B, Daxin, P.D, Sonecha, R.J and Mehta, K.S (2014) Analysis of engineering properties of black cotton soils and stabilization by lime:Journal of Engineering Research and Applications ISSN: 2248-9622 Vol 4, issue 5 (version 3) pp. 25-32

Gakubia R, Pokorski U and Onyango P (2010) Upscaling Access to Sustainable Sanitation. Follow-up Conference of the International Year of Sanitation, Tokyo Japan

Ghooyt, V.G. (1994) Property marketing study III: Study guide 3, Johannesburg: National Property Education Committee pp. 12-16

Holden R - (2011) 'Sustainable Sanitation Systems' in Sanitation Matters. A magazine for Southern Africa Issue 22011 
Independent Electoral Boundaries Commission. (2015). List of counties, constituencies and county assembly wards. Retrieved August 18, 2016, from http://www.iebc.or.ke/index.php/2015-01-15-11-1024/downloads/category/ boundaries

Ingallinela, A.M, Sanguinetti, G and T, Koottatep, Montanegro, A and M. Strauss - (2002). The Challenge of Fecal Sludge Management in urban areas - strategies, regulations and treatment options. Water, Science and Technology 46:10.pp 285-294 IWA, Publishing.

International Ecological Engineering Society, IEES (2006) Challenges in developing an institutional framework http://swmm.info/sites retrieved 3/9/18

Irrigation Act No 13 (2013). Revised edition (pp. 1-14). National Council for Law Reporting.

Jones, D.S Eales, K \&Tyers, L, (2006) Sanitation Partnerships: Harnessing their Potential for urban On-Site Sanitation. Building Partnerships for Development in Water and Sanitation retrieved from http://www.bpds.org

Jones, S (2011) 'Urban Sanitation in SADC, Challenges and Opportunities' in Sanitation Matters. A magazine for Southern Africa Issue 2-2011

Kagwi, M.L (2010) Adequacy and efficiency of sanitation facilities for urban housing: A case of Zimmerman area, Nairobi county. Unpublished BA planning research project University of Nairobi pp 1-79

Kakoi, O. (2013) Institutional framework for the management of peri-urban areas in Kenya: The case of Ongata Rongai. Unpublished MA thesis University of Nairobi pp1-139

Kothari, C.R. (2004) Research Methodology. Methods and techniques. $2^{\text {nd }}$ revised edition. Pp. 1-401 New Age International P (limited) Publishers

Krejcie, R. V. and Morgan, D. W. (1970) Determining sample size for research activities. Educational and psychological measurement 30 pp. 607-610 retrieved from www.e-bookspdf.org/viewlast accessed on 29/7/15

Kumar, R (2005) Research Methodology. A step by step guide for beginners. $2^{\text {nd }}$ Edition. Pp. 1-327 Sage Publications. India

Kvarnstrom, J and Kvarnstrom,E (2005) A review of sanitation regulatory frameworks. Report 1Stockholm Environment Institute pp 1-58

Land Act. (2012). (pp. 1-121). National Council for LawReporting.

Michels, A, and Graaf, L,D (2010) Examining citizen participation : Local participatory policy making and democracy Local Government Studies vol 30 issue 4 pp 477-49

Mugenda, A. G (2011) Social Science Research. Applied Research and Training Services. Arts Press Nairobi Pp. 1350

Muhele, M (2016)Factors influencing sanitation practices in Kibera urban informal settlements in Nairobi Kenya. Unpublished MA thesis University of Nairobi pp 1-81

Moseti, Y. Kimani, S and Mutua, B (2009) the linkage between settlement profile and choice of sanitation system in peri-urban areas. A case study of Nakuru htpp://www.researchgate.net/publication retrieved 20/9/18

Murray, A (2012) Burn it idea: let the market place solve the sanitation crisis.Pp. 63 Mansueto ventures LLC

Okumu, J. O. \& Oosterveer, P. (2010). Providing sanitation for the urban poor in Uganda. In Social perspectives on the sanitation challenge (pp. 49-66). Dordrecht: Springer. https://doi.org/10.1007/978-90-481-3721-3

Olukanni, D. O., Azuh, D. E., George, T. O., Ajayi, M. P., \& Emenike, P. C. (2014). The relevance of policy and practice on sanitation effort in developing nations: The experience of a semi urban city in south-west Nigeria. Proceedings of the International Conference of Education, Research and Innovation (pp. 1-9), Seville. Organization for Economic Cooperation and Development.

Omambia, A.N (2010) Sanitation in urban slums:perception, attitude and behavior. The case of Kibera, Nairobi Kenya Environmental Science pp 470-480

Parkinson, J, Luthi, C.J, and Walther, D (2014) Sanitation 21 A planning framework for improving city wide sanitation services pp. 1-180 IWA, GTZ, Eawag (sandec)

Peters, D (2018) Building an institutional framework http//sswm.info/water-nutrient-cycle/waterpurification/softwares/creating and enabling -environment/building an institutional framework-wp retrieved $3 / 9 / 18$

Physical Planning Act. (2012). Chapter 286 (pp. 1-84). NationalCouncil for Law Reporting. 
Mutua, J. K. M., Agwata, J., Anyango, S., \& Oguge, N. (2018). Appraising Policy, legal and Institutional Frameworks used in promoting Sustainable Sanitation Management Approaches in Mavoko Municipality within Machakos County. Advances in Social Sciences Research Journal, 5(10) 569-589.

Pujari, P.R, Padmaker, C, Labsetwar, P.K, Mahore, P and Ganguly, A.k (2012) National Environmental Engineering Research Institute. Environmental Monitoring Assessment 184:1 pp251-263

Republic of Kenya (2010) Constitution of Kenya Revised second edition, pp. 1-191 National Council for Law Reporting

Republic of Kenya. (2012). Kenya Health Policy 2012-2030pp.1-49. National Council for Law Reporting.

Republic of Kenya (2016) Machakos County Gazette Supplement Acts. The Machakos County Appropriation Act No 3 of 2016. Pp. 1-7 Government Press Nairobi

Republic of Kenya. (2013). National Environment Policy pp.1-53.

Republic of Kenya (2015) Kenya National Bureau of Statistics. Demographic and Health Survey 2014.

Republic of Kenya (2016-2030) National Environmental Sanitation and Hygiene Policy. Pp. 1-112 Nairobi

Republic of Kenya. (2016). National Spatial 2015-2045 optimal productivity, sustainability efficiency and equity in the use of our land and territorial space pp. 1-161 Nairobi: Government Printer.

Republic of Kenya. (2004). Sessional paper no. 3 of 2004 on National Housing Policy for Kenya pp. 1-141. NationalCouncil for Law Reporting.

Republic of Kenya. (2009). Sessional paper no. 3 of 2009 on National Land Policy pp. 1-64 Nairobi: Government Printer.

Republic of Kenya. (2017). Sessional paper no. 1 of 2017 on National Land Use Policy pp. 1-72 Nairobi: Government Printer.

Republic of Kenya. (2016). Sessional paper no. 1 of 2016 on National Urban Development Policy pp. 1-57 Nairobi: Government Printer.

Republic of Kenya. (2013). Spatial planning concept for the Nairobi Metropolitan Region (pp. 10.25-10.32). Nairobi.

Sathyanarayana, V (2017) Overview of legal and institutional frameworks. Infrastructure Development Corporation (Karnataka) Ltd Bengaluru http://smartnet.niua.org/sites retrieved 3/9/18

Sigel, K, Altantul, K and Basandorj (2012) Environmental Earth Sciences 65:4pp. 1561-1566

Sheillah Simiyu (2017) Preference for and characteristics of an appropriate sanitation technology for the slums of Kisumu, Kenya, International Journal of Urban Sustainable Development, 9:3, 300-312, DOI: 10.1080/19463138.2017.1325366

Steiner, S.M (2008) the impact of institutional frameworks in private sector participation in water supply and sanitation. The case of the management contract for water and waste water services in the Amman Government. IEE Working Paper Institute of Development Research and Development Policy vol 187 pp 1-87

Songa, P, Rumohr, J and Musota R (2015) Policy and institutional framework considerations in the implementation of catchment based water resources management in Uganda: highlights from the river Rwizi catchment. WIT Transaction on ecology and the environment vol 196 pp15-26

Sustainable sanitation alliance SuSanA (2008) Towards more sustainable solutions version 1.2 pp 1-4

Tilman, S, Russel, K, Page, L, Kramer, S and Davis, J. (2015) Container based sanitation: assessing costs and effectiveness of excreta management in cap Haitren, Haiti. Environment and Urbanization International Institute for Environment and Development (IIED) vol.27 (11) 89-104 doi:10.1177/0956-247815572746

Tumwebaze, I.K, Orach, C.G, Nakayaga, J.K, Karamagi, C, Luethi, C and Niwagaba, C (2011) Ecological Sanitation Coverage and Factors Affecting Its Uptake In Kabale Municipality, Western Uganda. International Journal of Environmental Health Research 21: 4pp. 294-305

United Nations Development Programme (UNDP), (2015) Sustainable development goals retrieved from http://www.undp.org/content/undp/en/home/sdgoverview/post-2015 development agenda/goal-6html last accessed $17 / 8 / 16$

Urban Areas and Cities Act. (2011). pp 1-4). National Council for Law Reporting.

Water Act (2016) pp. 1-116 National Councilfor Law Reporting.

Water and Sanitation Program-Africa Region. (2011) Water Supply and Sanitation in Kenya. Turning Finance into Services for 2015 and Beyond. 
World Bank (2016) Kenya Urbanization Review Executive Summary. pp. 1-21 World Bank Group, Sweden

World Health Organization, WHO (2018) Chapter 3 Sanitation and hygiene policies

http://www.who.int/water_sanitation_health/hygiene/santygpromo3.pdf retrieved 3/9/18

World Health Organization, WHO/UNICEF (2013) Global Progress on Sanitation and Drinking Water, 2013

Update.World Health Organization Press, Geneva 